Secondary Metabolite from Endophytic Fungi Aspergillus sp....(Muharni et al.)

\title{
SECONDARY METABOLITE FROM ENDOPHYTIC FUNGI Aspergillus sp. THE LEAVE OF KUNYIT PUTIH (Curcuma zedoaria (BERG) ROSCOE)
}

\section{METABOLIT SEKUNDER DARI JAMUR ENDOFITIK Aspergillus sp. DAUN TUMBUHAN KUNYIT PUTIH (Curcuma zedoaria (BERG) ROSCOE)}

\author{
Muharni $^{1 *}$, Fitrya ${ }^{2}$, Widia Purwaningrum ${ }^{1}$, and Ahmad Yogi Nugraha ${ }^{1}$ \\ ${ }^{1}$ Department of Chemistry, Faculty of Mathematics and Natural Sciences, Sriwijaya \\ University, Palembang, Indonesia \\ ${ }^{2}$ Department of Pharmacy, Faculty of Mathematics and Natural Sciences, Sriwijaya \\ University, Palembang, Indonesia \\ *email: muharnimyd@yahoo.co.id
}

Received 9 February 2016; Accepted 2 May 2016; Available online 16 May 2016

\begin{abstract}
The compound from endophytic fungi of Aspergillus sp. from leaves of kunyit putih (Curcuma zedoaria (Berg.) Roscoe) has been isolated. Isolation begins with cultivation of Aspergillus sp. in 18 L PDB's media (Potato Dextrose Broth) for 28 days. The liquid cultivation medium was extracted by partitioning method using ethylacetate and then evaporated. The extract was separated and purified by chromatography techniques. Elucidation stucture of the isolated compound was analysis by spectroscopic method NMR 1D and 2D. Antibacterial activity of isolated compound was tested using the disc diffusion method at concentrations 2500, 1000, 500, and $125 \mathrm{ppm}$. The isolated compounds obtained in the form of a yellow oil $(24.30 \mathrm{mg})$. The ${ }^{13} \mathrm{C} N \mathrm{NR}$ spectrum indicated 24 signals of carbon and base on analysis spectrum DEPT 135 showed 5 signal methynes carbon, 1 signals methylene, 9 signals of methyl and 9 signals quarternary carbon. These signals from ${ }^{1} \mathrm{H}$ and ${ }^{13} \mathrm{C}$-NMR suggested that this compound contained aromatic group and four carbonyl. The isolated compound show antibacterial activity at concentration $2500 \mathrm{ppm}$ which inhibition zone for E. coli, S. dysenteriae, S. aureus, B. subtilis were $10.3 ; 8.3 ; 8.4$; and $7.8 \mathrm{~mm}$, respectively. Based on the analysis result of NMR 1D and 2D, the compound was methyl 6-(5'-(2"-acetoxy-2"-methylpropanoyl)-3"methyl-2'-(3"'-methylbutanoyl)phenyl)-3-methylbutanoate and has weak antibacterial activity.
\end{abstract}

Keyword: Aspergillus sp., Curcuma zedoaria, endophytic fungi

\begin{abstract}
ABSTRAK
Telah diisolasi satu senyawa metabolit sekunder dari jamur endofitik Aspergillus sp. pada daun tumbuhan kunyit putih (Curcuma zedoaria (Berg) Roscoe). Isolasi diawali dengan kultivasi jamur Aspergillus sp. dalam 18 L media PDB (Potato Dextrose Broth) selama 48 hari. Medium kultur cair diekstraksi secara partisi menggunakan etil asetat dan dievaporasi. Ekstrak pekat etil asetat dipisahkan dan dimurnikan menggunakan teknik kromatografi. Penentuan struktur senyawa hasil isolasi dilakukan dengan cara spektroskopi NMR 1D dan 2D. Aktivitas antibakteri dari senyawa hasil isolasi telah diuji menggunakan metode difusi cakram dengan konsentrasi 2500, 1000, 500, 125 ppm. Dari penelitian ini diperoleh satu senyawa murni berupa minyak berwarna kuning sebanyak 24,30 mg. Spektrum ${ }^{13} \mathrm{C}$ NMR menunjukkan adanya 24 sinyal karbon dan berdasarkan spektrum DEPT terdiri dari 5 karbon metin, 1 karbon metilen, 9 karbon metil dan 9 karbon
\end{abstract}


kwarterner. Senyawa hasil isolasi menunjukkan aktivitas antibakteri pada konsentrasi 2500 ppm dengan diameter zona bening berturut-turut untuk E.coli, S. dysenteriae, S.aureus, B. subtilis 10,$3 ; 8,3 ; 8,4$; dan 7,8 mm. Berdasarkan analisis data spektroskopi NMR 1D dan 2D maka diusulkan senyawa hasil isolasi adalah metil 6-(5'-(2"-asetoksi-2"metilpropanoil)-3"-metil-2'-(3"'-meilbutanoil)fenil)-3- metilbutanoat dan memiliki sifat aktivitas antibakteri yang lemah.

Kata kunci: Aspergillus sp, Curcuma zedoaria, jamur endofitik

\section{INTRODUCTION}

Endophytic fungi are defined as fungi which spend the whole or part of their lifecycle colonizing inter and intracellularly inside the healthy tissue of the host plants, typically causing no apparent symptoms of disease (Zhang, Song, \& Tan, 2006; Rodriguez., White, Arnol, \& Reman, 2009). Plant endophytic fungi have been recognized as an important and novel resource of natural bioactive products with potential application in agriculture, medicine and food industry (Gunatilaka, 2006; Verma, Kharmar, \& Strobel, 2009). Novel antibiotics, antimycotics, immunosuppressants, and anticancer compounds are rarely founded after the isolation and culturing of individual endophytes which followed by purification and characterization of some of their natural products (Strobel, Daisy, Castillo, \& Harper, 2004).

Endophytic fungi have been found in each plant spesies examined, and estimated that there are over one million fungal endophytes existed in the nature. Traditionally Curcuma zedoaria known as herbal medicine which possessing many biological activities. Some bioactive compounds that contained in Curcuma zedoaria have been reported are furanodiene, furanodienone, zedorone, curzerenone, curzeone, germacrone, 13hydroxy germacrone, dihydrocurdione, curcumenone and zedoaronediole which is of sesquiterpenoid. (Makabe, Maru, Kuwabara, Kamo, \& Hirota, 2006). Curcuma zedoaria also contains epikurzerenone and kurzerene compounds (Mau, et.al. 2003) and isocurcumenol which have antitumour effects (Lakshmi, et. al. 2011) and triterpenoid compounds.

Many endophytic bacterial live in association with their host and may play an important biological roles. Sulistiyani, Lisdiyanti, and Lestari, (2014) have been investigate the endophytic bacterial diversity associated with Curcuma zeodaria and total of 207 bacterial colonies were isolated from rhizomes, stems, and leaves and 73 endophytic bacteria were selected based on morphological characteristics.

Research about secondary metabolite that contained in endophytic fungi of Curcuma zedoaria also has been reported but still limited. Muharni, Fitrya, Ruliza, Susanti and Elfita (2014b) have been reported two compounds bis-(2ethylhexyl)phtalat and 3-(2,5-diacethyl)3,4-dihydroxyphenyl)-butan-2-

nylpropionate from endophytic fungi Penicillium sp. Compound 2 (Pyranon derivated) show antibacterial activity to $S$. Aureus and antioxidant activity by DPPH method with $\mathrm{IC}_{50} 16.05 \mu \mathrm{g} / \mathrm{mL}$ (Muharni, Fitrya, Milanti \& Elfita, 2014a). Invivo assay as antibacterial from endophytic fungus Penicillium $s p$ extract has been done used mice (Mus musculus) (Muharni, Heni, Fitrya \& Roni, 2015). To complete profile of the chemical constituents of endophytic microbe of Curcuma zedoaria, in this paper we will be explained isolation of secondary metabolite compound from endophytic fungi Aspergillus sp in leaves of Curcuma zedoaria. The antibacterial activity of isolated compound have been done. 


\section{EXPERIMENTAL SECTION}

\section{Materials and Equipment}

The leaves of kunyit putih were collected on Mei 2013 from the Indralaya, Ogan Ilir, South Sumatra. Material for isolation and cultivation endophytic fungi: ethanol $70 \%, \mathrm{NaOCl}$, chloramphenicol, potato dextrose broth (PDB), potato dextrose agar (PDA). Material for isolation compound: silica gel 60 (70-230 mesh.), thin layer chromatography (TLC) using Merck (Art.5554), silica gel $60 \mathrm{~F}_{254}$, $n$-hexane, ethylacetate, and methanol. The organic solvents were used from distilled technical grade. Material for antibacterial activity assay: nutrient agar (NA) and nutrient broth (NB), and ampicillin.

The apparatus in the research were counter colony, autoclave, incubator, water bath, microscope, magnetic hotplate, UV lamp, column chromatography and generally apparatus in organic and microbiology laboratory, melting point was determined using Fisher John Apparatus. NMR spectra were recorded at $500 \mathrm{MHz}\left({ }^{1} \mathrm{H}\right)$ and $125 \mathrm{MHz}$ $\left({ }^{13} \mathrm{C}\right)$ on JEOL JNM ECA-500 spectrometer.

\section{Procedure}

\section{Isolation of endophytic fungus}

The study begins with the isolation of endophytic fungi from leaves Curcuma zedoaria plant. The procedure refers to Muharni el al. (2014) with slight modifications. The leaves sample were washed and sterilized in $70 \%$ ethanol for 5 min and $0.5 \% \mathrm{NaOCl}$ for $5 \mathrm{~min}$ and then washed with sterile distilled water. The segment were placed on petri-plates containing potato dextrose agar medium (PDA). The plates were incubated at $25 \pm 2$ ${ }^{\circ} \mathrm{C}$. The plant segment observed every day to see the growth of endophytic fungus. Fungal colony that shows a different characteristic further purified by transferring it in the PDA medium other then some subculture to obtain pure fungal cultures (Aspergillus sp.) (Barik, Tayung,
Jagadev, \& Duta, 2010; Kour et al., 2008; Eyberger, Dondapati, \& Porter, 2006)

\section{Identification of the endophyte}

The endophytic fungal strain was identified by the morphological method. The morphological examination was performed by scrutinizing the fungal culture, the mechanism of spore production, and the characteristics of the spores. All experiments and observations were repeated at twice (Guo et al., 2008) .

\section{Cultivation of pure fungal strain}

The procedure for the cultivation refers to Muharni et al., 2014a with slight modifications. Cultivation of fungus that have been pure (Aspergillus sp), (a small park) were transferred into the medium under sterile conditions to the PDB medium. To isolate the secondary metabolites, the fungal strains were static cultivated in 30 flasks each containing $600 \mathrm{~mL}$ of PDB medium and incubated for 28 days at room temperature, so the metabolites sekunderrnya will enter into PDB medium. (Xu et al., 2008). Furthermore filtered to separate filtrate and biomass. The Filtrate containing secondary metabolites, then partitioned with ethylacetate solvent. Then the ethyl acetate phase was further concentrated by rotary vacuum evaporator at $40{ }^{\circ} \mathrm{C}$ and obtained ethyl acetate fraction of liquid cultures $(5,0 \mathrm{~g})$.

\section{Isolation secondare metabolite from ethylacetate fraction of endophytic fungus}

Concentrated ethylacetate from Aspergillus sp (5.0 g) were isolated using column chromatography with silica gel 60 as stationary phase. The solvent system used for chromatography was $n$-hexane with increasing portion of EtOAc (gradient elution system). The ratio of the solvent between $n$-hexane and EtOAc were $100: 0,90: 10,10: 90$ ). Fraction were collected every $10 \mathrm{~mL}$ and each fraction was tested by TLC. The spot were detected by UV light (254 and $366 \mathrm{~nm}$ ). Fraction having spots with the same Rf 
value were combined and treated as a group. Fraction $2^{\text {nd }}(0.9 \mathrm{~g})$ was rechromatography using the same method to give pure compound form yellow oil (24.3 mg) (Hundley, 2005). The molecular structure of pure compound were determined on the basis of spectroscopic analysis $\left({ }^{1} \mathrm{H}-\mathrm{NMR},{ }^{13} \mathrm{C}\right.$ NMR, DEPT, HMQC, HMBC, and COSY).

\section{Antibacterial activity}

The antibacterial activity assay used: Escherichia coli, Sigella dysentryae, Staphylococcus aureus and Bacillus subtilis. The antibacterial activity were determined by disc diffusion method were described previously for the preliminary of antibacterial activity (Lai, Chyau \& Mau, 2004). A sterile paper disc was impregnated with test material and the disc was placed on the nutrient agar medium. Plates were then incubated at $37{ }^{\circ} \mathrm{C}$ for $72 \mathrm{~h}$ under anaerobic conditions. All disc diffusion tests were performed in three separated experiments and the antibacterial activity was expressed as the mean of inhibition diameters $(\mathrm{mm})$. The test material was preparated in various concentration and as standard used ampicillin $10 \mathrm{ppm}$.

\section{RESULT AND DISCUSSION}

\section{Isolation and Identification The Secondary Metabolits}

The fungus strain was identified as Aspergillus sp. Base on literature study Aspergillus sp species isolated as endophytes were usually obtained from several plant spesies such as, endophytic fungi Aspergillus niger from stem bark of Garcinia griffithii (Elfita, Muharni, Munawar, \& Aryani, 2012), Aspergillus niger var taxi from Taxus cuspidata (Zhou et al., 2009), Aspergillus fumigates from fruit of G. griffithii (Elfita, Muharni, \& Indah, 2011), and Podocarpus sp (Sun, Rang \& Wang, 2008), Aspergillus flavus from sambiloto (Andographis peniculata Nees) (Elfita, Muharni, Munawar, Salni \& Oktasari, 2010).

Fungus Aspergillus sp after cultivation in media 18L PDB then extracted with ethyl acetate and obtained 5 $\mathrm{g}$ of concentrated ethyl acetate extract. $5.0 \mathrm{~g}$ of ethylacetate extract after being separated by column chromatography techniques to yield pure compound in the form of yellow oil (24.3 mg) (Figure 1).
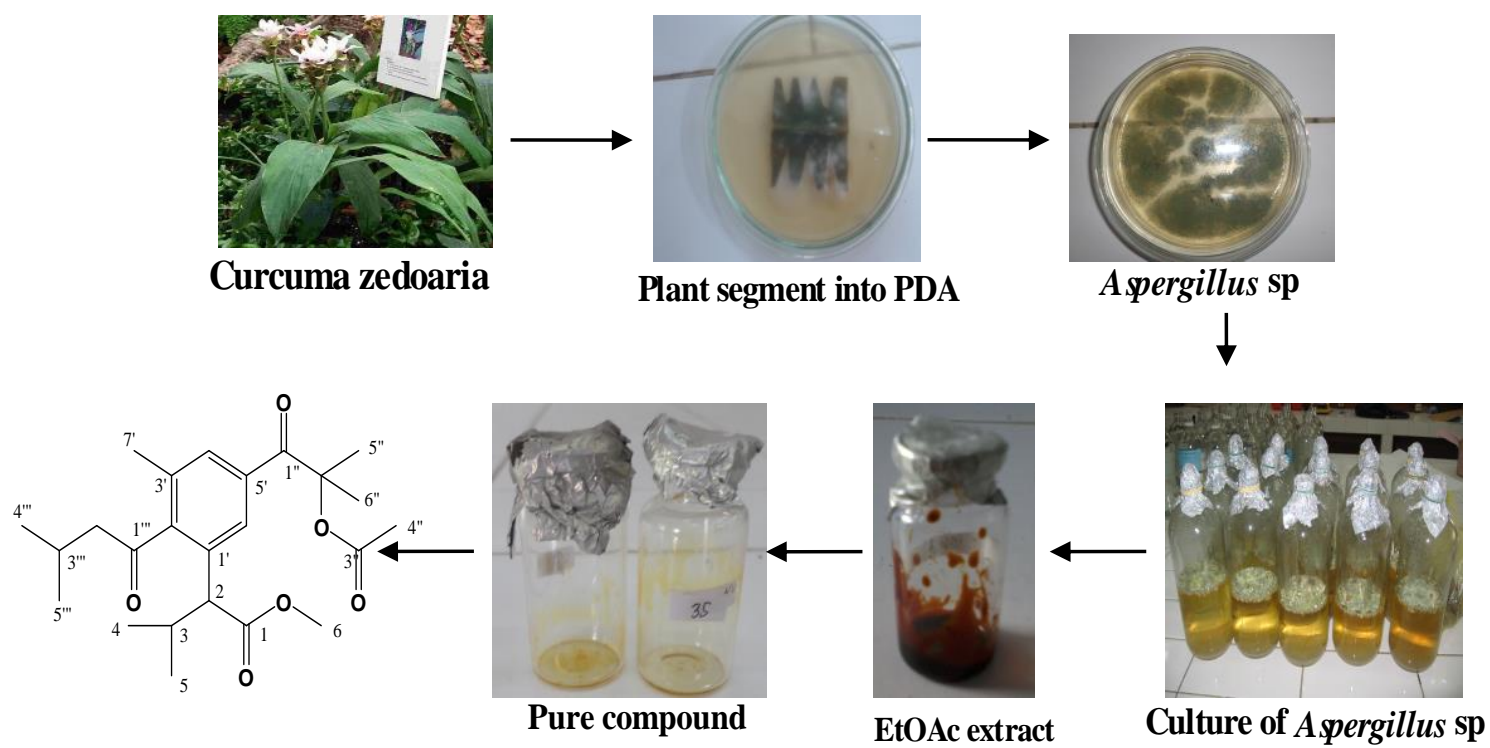

Figure 1. Isolation of the compound from ethyl acetate extract of Aspergillus sp from the leaves of Curcuma zedoaria 
Table 1. The NMR data of isolated compound, recorded at ${ }^{1} \mathrm{H}-500 \mathrm{MHz} ;{ }^{13} \mathrm{C}-125 \mathrm{MHz}$, spectral data of recorded in $\mathrm{CDCl}_{3}$

\begin{tabular}{|c|c|c|c|c|c|}
\hline NO. C & $\delta_{c}(p p m)$ & DEPT & $\begin{array}{c}\delta_{H} \text { ppm }(\Sigma \mathrm{H}, \text { multiplicity, } \\
J(\mathrm{~Hz})\end{array}$ & HMBC & COSY \\
\hline 1 & 174.6 & $\mathrm{C}$ & & & \\
\hline 2 & 39.8 & $\mathrm{CH}$ & $2.46(1 \mathrm{H}, m)$ & & \\
\hline 3 & 27.4 & $\mathrm{CH}$ & $1.70(2 \mathrm{H}, m)$ & & $0.93 ; 1.18$ \\
\hline 4 & 11.5 & $\mathrm{CH}_{3}$ & $0.93(3 \mathrm{H}, d, J=7.75)$ & $27.4 ; 40.4$ & 1.70 \\
\hline 5 & 17.9 & $\mathrm{CH}_{3}$ & $1.18(3 \mathrm{H}, d, J=7.75)$, & $27.4 ; 40.4$ & 1.70 \\
\hline 6 & 57.1 & $\mathrm{CH}_{3}$ & $3.80(3 \mathrm{H}, s)$ & 174.6 & \\
\hline 1 ' & 167.5 & $\mathrm{C}$ & & & \\
\hline 2 ' & 165.2 & $\mathrm{C}$ & & & \\
\hline $3^{\prime}$ & 98,7 & $\mathrm{C}$ & & & \\
\hline $4^{\prime}$ & 99,1 & $\mathrm{CH}$ & $5,93(1 \mathrm{H}, s)$ & 167,$1 ; 98.5$ & \\
\hline $5^{\prime}$ & 167.1 & $\mathrm{C}$ & & & \\
\hline $6^{\prime}$ & 96.5 & $\mathrm{CH}$ & $5.56(1 \mathrm{H}, s)$ & $\begin{array}{c}174.6 ; \\
196.7\end{array}$ & \\
\hline 7 ' & 8.3 & $\mathrm{CH}_{3}$ & $1.94(3 \mathrm{H}, s)$ & $\begin{array}{c}165.2 \\
167.1 ; 98.7\end{array}$ & \\
\hline $1 "$ & 196,7 & $\mathrm{C}$ & & & \\
\hline $2 "$ & 77.3 & $\mathrm{C}$ & & & \\
\hline $3 "$ & 175.7 & $\mathrm{C}$ & & & \\
\hline $4 "$ & 25.2 & $\mathrm{CH}_{3}$ & $1.65(3 \mathrm{H}, \mathrm{s})$ & & \\
\hline $5 "$ & 25.3 & $\mathrm{CH}_{3}$ & $1.61(3 \mathrm{H}, s)$ & $77.3 ; 196.7$ & \\
\hline $6 "$ & 26.7 & $\mathrm{CH}_{3}$ & $1.63(3 \mathrm{H}, s)$ & 77.3 & \\
\hline $1 "$ & 200.9 & $\mathrm{C}$ & & & \\
\hline $2 "$, & 40.4 & $\mathrm{CH}_{2}$ & $2.46(2 \mathrm{H}, m)$ & & \\
\hline $3 " \prime$ & 26,7 & $\mathrm{CH}$ & $1.67(1 \mathrm{H}, m)$ & $77.3 ; 200.9$ & $0.85 ; 1.17$ \\
\hline $4 "$, & 16,5 & $\mathrm{CH}_{3}$ & $1.17(3 \mathrm{H}, d, J=7.15)$ & $26.7 ; 40.4$ & $1.67 ; 2.46$ \\
\hline $5 "$ & 11,7 & $\mathrm{CH}_{3}$ & $0.85(3 \mathrm{H}, d, J=7.15$ & $26.7 ; 40.4$ & 1.67 \\
\hline
\end{tabular}

The ${ }^{1} \mathrm{H}$ NMR data (Table 1) disclosed the presence of two protons at $\delta_{\mathrm{H}} \quad 5.93$ and $5.56 \mathrm{ppm}(1 \mathrm{H}, s)$ were characteristic for vinyl proton. The proton signal at $\delta_{\mathrm{H}} 3.80 \mathrm{ppm}(3 \mathrm{H}, s)$ was assigned to a methoxy group. Furthermore, the presence proton signals at $\delta_{\mathrm{H}} 2.46$ each $(3 \mathrm{H}, m)$ for one proton methylene and one proton methine, signals at $1.67(1 \mathrm{H}, m)$, and $1.70(1 \mathrm{H}, m)$ for two methine groups. The ${ }^{1} \mathrm{H}$ NMR data also indicated the presence of eight methylprotons at $\delta_{\mathrm{H}} 1.94 \mathrm{ppm}, \delta_{\mathrm{H}} 1.65$ $\delta_{\mathrm{H}} 1.63 \mathrm{ppm}$ and $1.61 \mathrm{ppm}, \delta_{\mathrm{H}} 1.18(3 \mathrm{H}$, $d, J=7.75), 0,93(3 \mathrm{H}, d, J=7.75), 1.17$ ppm $(3 \mathrm{H}, d, J=7.15)$, and $0.85 \mathrm{ppm}(3 \mathrm{H}$, $d, J=7.15$.).

The ${ }^{13} \mathrm{C}$ NMR spectrum (Figure 2) indicated 24 signal carbon consist that 10 signals as $\mathrm{C} \mathrm{sp}{ }^{2}$ and 14 signals as $\mathrm{C}$ $\mathrm{sp}^{3}$. Base on analysis spectrum DEPT 135 showed 5 signal methines carbon at $\delta_{\mathrm{C}}$
$99.1 ; 98.5 ; 38.9 ; 27.4 \mathrm{ppm}$ and $\delta_{\mathrm{C}} 26.7$ ppm , 1 signals methylene carbon at $\delta_{\mathrm{C}}$ 40.4 ppm, 9 signals methyl carbon at $\delta_{\mathrm{C}}$ $57.1 ; 26.7 ; 25.3 ; 25.2 ; 17.9 ; 16.5 ; 11.7$; 11.5 and $\delta_{\mathrm{C}} 8.3 \mathrm{ppm}$ and 9 signal quarternary carbon at $\delta_{\mathrm{C}} 200.9 ; 196.7$; $175.6 ; 174.5 ; 167.3 ; 167.1 ; 165.1,98.7$ and $\delta_{\mathrm{C}} 77.3 \mathrm{ppm}$.

Signals carbon at $\delta_{C} 196.7 \mathrm{ppm}$ and 200.9 ppm indicated these compound have two carbonyl groups and 175.6 and 174.5 caracteristic for ester carbonyl. Signal methyl carbon at $\delta_{\mathrm{C}} 57.1 \mathrm{ppm}$ characteristic for signal methoxy carbon. These signals from ${ }^{1} \mathrm{H}$ and ${ }^{13} \mathrm{C}-\mathrm{NMR}$ suggested that this compound contained aromatic group and four carbonyl group. The presences of the funcional groups above were suggested by the long range coupling $\mathrm{HMBC}$ and correlation of the chemical $\mathrm{H}$ and $\mathrm{C}$ shift for all protonnated carbons was determined based on the 
HMQC spectrum as summarized in Table 1.

NMR 2D analysis for HMQC spectrum showed the proton signal at $\delta_{\mathrm{H}}$ $5.93 \mathrm{ppm}$ and $\delta_{\mathrm{H}} 5.56 \mathrm{ppm}$ attached to carbon signal at $\delta_{\mathrm{C}} 99.1 \mathrm{ppm}$ and 98,5 respectively and proton at $\delta_{\mathrm{H}} 3.80$ attached to carbon at $\delta_{C} 57.1 \mathrm{ppm}$. HMBC spectrum showed proton at $\delta_{\mathrm{H}}$ 5.93 was correlated to carbon at $\delta c 98.5$ and $\delta \mathrm{c} 167.1 \mathrm{ppm}$, while proton at $\delta_{\mathrm{H}} 5.56$ showed correlation to carbon at $\delta_{C} 174.6$ and $196.7 \mathrm{ppm}$. This data indicated that two proton vinilic was not place at the carbon besides it. Further HMBC spectrum showed correlation proton of $\delta_{\mathrm{H}}$ $3.80 \mathrm{ppm}(3 \mathrm{H}, s)$ to carbon at $\delta_{C} 174.6$ ppm indicated as proton methoxy from ester group.

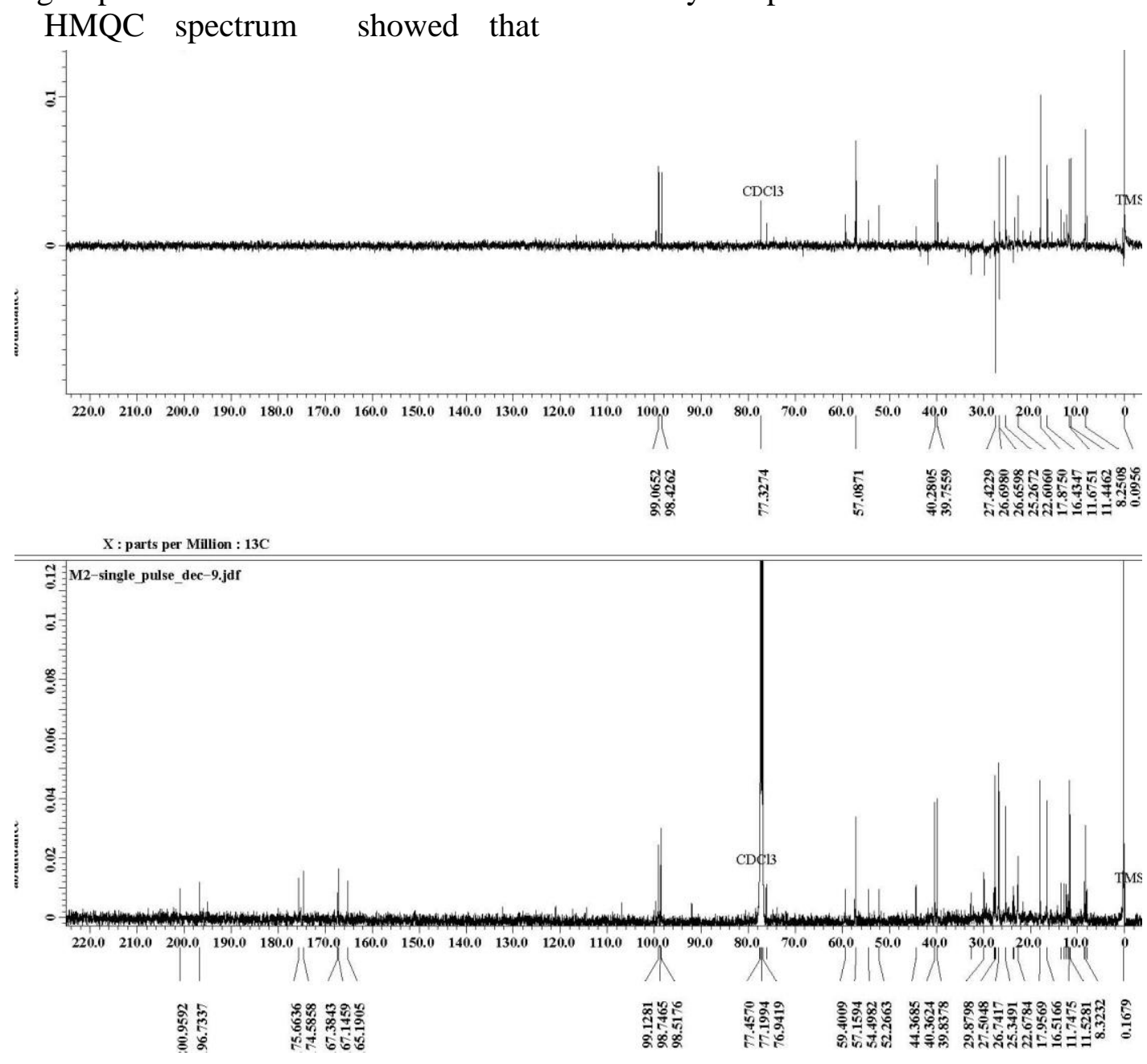

Figure 2. ${ }^{13} \mathrm{C}$ NMR spectrum isolated compound proton at $\delta_{\mathrm{H}} 1.61$ attached to carbon at $\delta \mathrm{c}$ 25.3 and HMBC spectrum showed that proton at $\delta_{\mathrm{H}} 1.61$ was correlated to carbon $\delta \mathrm{c} 77.3$ dan $\delta \mathrm{c} 196.7 \mathrm{ppm}$. While proton at $\delta_{\mathrm{H}} 1.63 \mathrm{ppm}$ at HMQC spectrum showed attached to carbon at $\delta_{C} 26.7 \mathrm{ppm}$ and HMBC spectrum showed correlation to carbon at $77.3 \mathrm{ppm}$. This data indicated that two proton methyl were bounded at the same carbon that $\delta_{C} 77.3 \mathrm{ppm}$. The proton at $\delta_{\mathrm{H}} 1.94$ at $\mathrm{HMQC}$ spectrum showed attached to carbon at $\delta_{C} 8.3 \mathrm{ppm}$ and HMBC spectrum showed correlated to carbon at $\delta_{C} 98.7$. Proton at $\delta_{\mathrm{H}} 2.46$ attached to carbon at 39.8 and $40.4 \mathrm{ppm}$ (Figure 3). This data supported that proton at $\delta_{\mathrm{H}} 2.46 \mathrm{ppm}$ were one signal methine proton and one as signal methylene proton. 


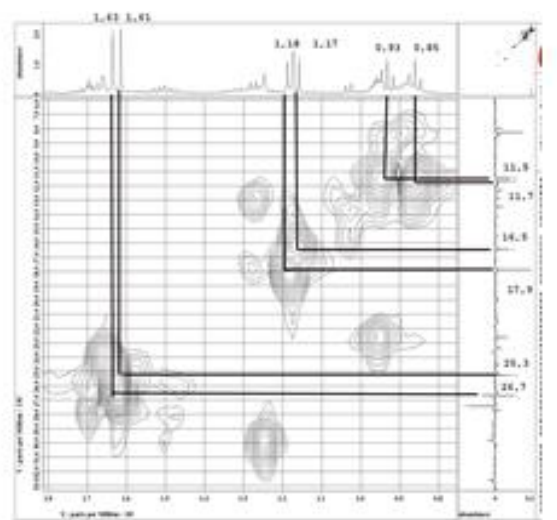

A

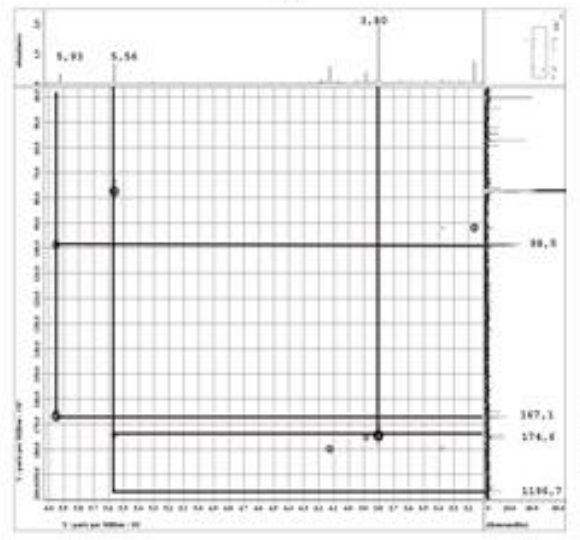

$\mathrm{C}$

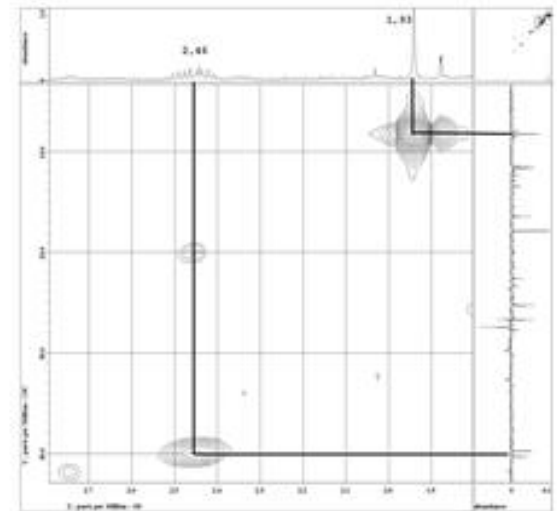

B

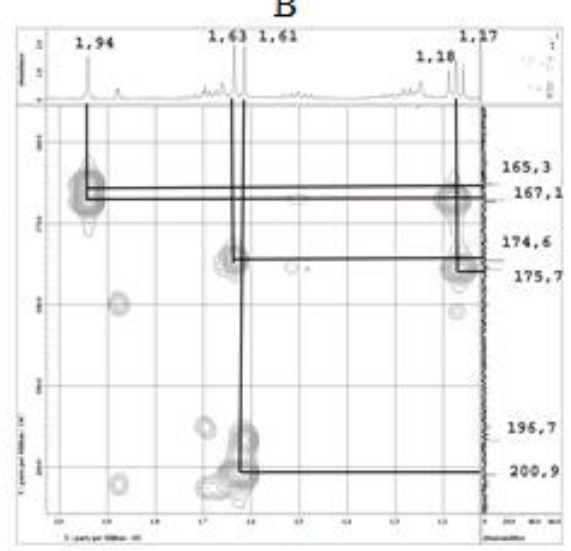

D

Figure 3. HMQC Spectrum (A, B) and HMBC Spectrum (C, D)

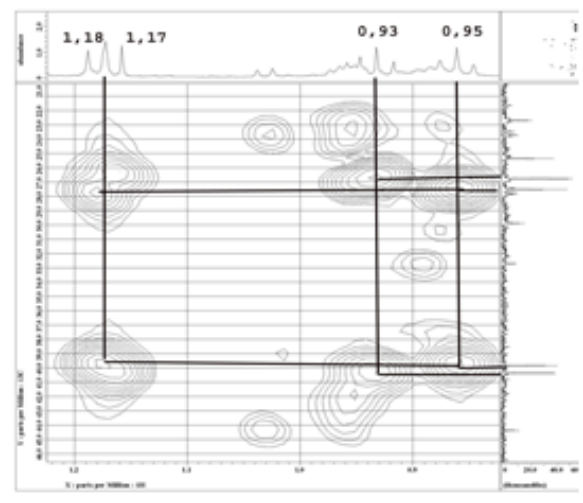

A

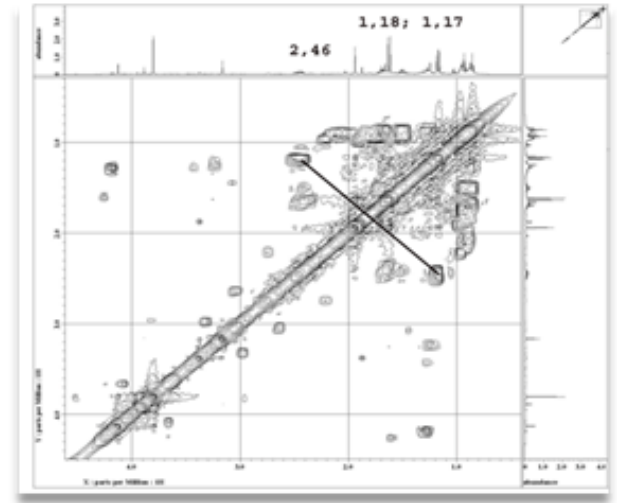

B

Figure 4. HMBC spectrum (A) and dan COSY spectrum (B)

Furthermore at HMBC spectrum showed correlation proton at $\delta_{\mathrm{H}} 1.94 \mathrm{ppm}$ to carbon $\delta$ c $165.2 ; \delta c 167.1$; and $\delta \mathrm{c} 98.7$ ppm indicated the proton attached at aromatic ring. HMQC spectrum also showed that proton at $\delta_{\mathrm{H}} 1.18$ and 0.93 ppm attached to carbon at $\delta \mathrm{c} 17.9 \mathrm{ppm}$, and $\delta \mathrm{c} 11.5 \mathrm{ppm}$, while HMBC spectrum (Figure 4) showed both of this proton was correlation to carbon $\delta c 27.4$ dan 39.8. Proton at $\delta_{\mathrm{H}} 1.17$ and $0.85 \mathrm{ppm}$ at HMQC spectrum showed attached to carbon at $\delta_{C}$ 16.5 and 11.7 ppm at HMBC spectrum showed both of this proton correlation to carbon $\delta \mathrm{c} 26.7 \mathrm{ppm} 40.4 \mathrm{ppm}$.

COSY spectrum (Figure 4) showed proton at $\delta_{\mathrm{H}} 1.17 \mathrm{ppm}$ and $0.85 \mathrm{ppm}$ each was correlated to proton at $\delta_{\mathrm{H}} 1.67 \mathrm{ppm}$ and 2.46, while that proton at $\delta_{\mathrm{H}} 0.93$ ppm and 1.18 correlated to proton at $\delta_{\mathrm{H}}$ $1.70 \mathrm{ppm}$. The presences of the functional groups above were suggested by the long 
range coupling HMBC experiment.

These spectroscopic data, therefore suggested that compound was identified as methyl 6-(5'-(2"-acetoxy-2"methylpropanoyl)-3"-methyl-2'-(3"'-

methylbutanoyl)phenyl)-3-

methylbutanoate. HMBC correlation and structure this compound showed at Figure 5. Exploration of secondary metabolites research needs to be done in order to get the profile of organic compounds produced by endophytic fungus of Curcuma zedoaria.

Based on the literature study, the biosynthetic pathways of secondary metabolites produced from endophytic fungus has not been found clearly. The substances isolated from endophytic have different biosynthetic pathways: isoprenoid, polyketide, amino acid derivatives, and belonged to diverse structural groups: terpenoids, steroids, xanthones, chinones, phenols, isocumarines, benzopyranones, tetralones, cytochalasines, and enniatines (Barbara, Christine, Anne, \& Kristen, 2002). Literature survey also showed these compounds have never found either of Curcuma zeodaria or host plants of other plants. This compound also not yet been found of other endophytic fungi, but the compounds proposed are similar to compounds that are reported of fungal endophytic dothiorelon B and dothiorelon $\mathrm{C}$, were isolated from microbial Dothiorella $s p$ who live on the leaves of the species Cynodon dactylon (L) (Poaceae) (Radji, 2005). Other similar compounds ever discovered was 2-\{4methyl-2-[(2-methylpropanoyl)oxy] phenyl \}oxiran-2-yl)methyl-3-methylbutanoic (Yannai, 2004) (Figure 6).

\section{Antibacterial Activity}

The antibactetrial activity of this compound was evaluated according to the method previously described. The antibacteiral properties of isolated compound was evaluated according to the method described previously (Lai, 2004 ). This compound showed inactive antibacterial for all bacterial test until concentration test $1000 \mathrm{ppm}$. This compound will show activity by concentration $2500 \mathrm{ppm}$ with the mean of inhibition diameters (mm) for E. coli, $S$. dysenteriae, S. aureus, B. subtilis 10,3 ; $8.3,8.4$; and $8.8 \mathrm{~mm}$ respectively and standard antibacterial ampicillin at concentration $10 \mathrm{ppm}$ showed inhibition diameters 7.5; 8.5; 7.0; and $9.5 \mathrm{~mm}$ respectively. Base on this data the compound show weak activity.

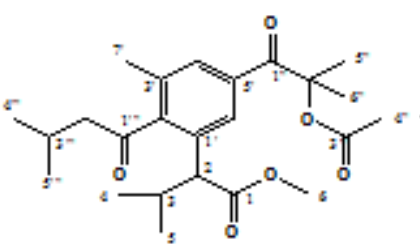

A

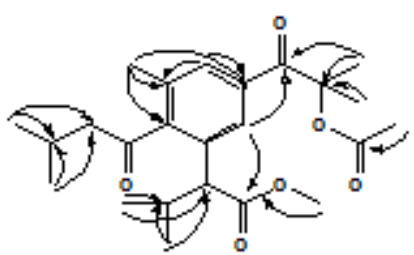

B

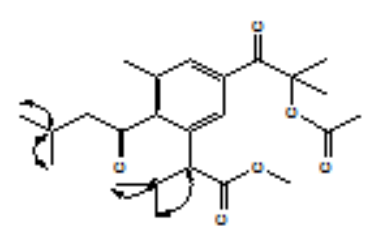

C

Figure 5. Structure, (A), HMBC Correlation (B) and COSY correlation (C) of isolated compound<smiles>C/C=C/C(=O)COC(=O)c1c(C)cc(O)cc1O</smiles>

Figure 6. Structure of dothiorelon B, dothiorelon C from microbial Dothiorella $s p$ and 2\{4-methyl-2-[(2-methylpropanoyl)oxy]phenyl\}oxiran-2-yl)methyl-3methylbutanoic. 


\section{CONCLUSION}

A new compound have been isolated from the endophytic fungi Aspergillus sp from the leaves of kunyit putih (Curcuma zedoaria). Based on spectroscopic analysis H-NMR and C-NMR (1D and 2D), was identified as methyl 6-(5'-(2"acetoxy-2"-methylpropanoyl) -3"-methyl2'-(3"'-methylbutanoyl)phenyl)-3-

methylbutanoic. Isolated compound showed weak antibacterial activity.

\section{ACKNOWLEDGEMENT}

The authors are grateful to the Directorate General of Higher Education which research grant Fundamental 2014 was supported this research.

\section{REFERENCE}

Barbara, S., Christine, B., Siegfried, D., Anne, K. R., and Kristen, K. (2002). Endophytic fungi: a source of novel biologically active secondary metabolites, Mycological Research, 106 (9), 996-1004

Barik, B.P., Tayung, K., Jagadev, N., and Dutta, S. K. (2010). Phylogenetic placement of an endophytic fungus Fusarium oxysporum isolated from acorus calamus rhizome with antimicrobial activity. European Journal Biological Science. 2(1), 816.

Elfita, Muharni, Munawar, Salni, dan A. Oktasari. (2010). Senyawa antimalaria dari jamur endofitik tumbuhan sambiloto (Andographis paniculata Nees. Jurnal Natur Indonesia 13(2) 123-129.

Elfita, Muharni, and T. Indah. (2011). Secondary metabolite of Aspergillus fumigatus, an endophytic fungi of the medicinal plant Garcinia griffithii. Makara Seri Sains, 15(2),124-128.

Elfita, Muharni, Munawar, and S. Aryani. (2012). Secondary metabolite from endophytic Fungi Aspergillus niger of the stem bark of Kandis Gajah
(Garcinia grfiffithii). Indonesian Journal Chemistry, l12(2), 195-200

Eyberger, A. L., Dondapati, R., and Porter, J.R. (2006). Endophytic fungal isolated from Podophyllum peltatum produce podophyllotoxin. Journal of Natural Products, 69(8), $1121-1124$.

Gunatilaka A. A. L. (2006). Natural products from plant-associated microorganisms, distribution, structural diversity, bioactivity, and implications of their occurrence. Journal of Natural Products. 69(3), 505-526.

Guo, L., Wu, J. Z., Han, T., Cao, T., Rahman, K., and Qin L.P. (2008). Chemical composition, antifungal and antitumor properties of ether extracts of Scapania verrucosa Heeg. and its endophytic fungus Chaetomium fusiforme. Molecules, 13(9), 2114-2125

Hundley, N.J. (2005). Struktur elucidation of bioactive compounds isolated from endophytes of Alstonia scholaris and Acmena graveolens. Thesis. Department of Chemistry and Biochemistry. Brigham Young University.

Kour, A., Shawl A.S., Rehman, S., Sultan p., Qazi, P. H., and Verma. (2008). Isolation and identification of an endophytic strain of Fikusarium oxysporum producing podophylotoxin from Juniperus recurva. World Journal of Microbiology and Biotechnology, 24(7), 1115-1121

Lai, E.Y.C., Chyau, C.C., and Mau, J.L. (2004). Antimicrobial activity and cytotoxicity of the essential oil of Curcuma zedoaria. American Journal of Chinese Medicine. 32(2): 281-290.

Lakshmi.S., Padmaja.G., and Remani. P. (2011). Antitumor effect of isocurcumenol isolated from Curcuma zedoaria rhizomes on human and murine cancer cells. 
International Journal Medicinal Chemistry, 2011, 1-13.

Makabe, H., Maru, N., Kuwabara, A., Kamo, T., and Hirota, M. (2006). Anti-inflammatory Sesquiterpenes from Curcuma zedoaria. Journal Natural Product, 20(7), 680-685.

Mau, J. L., Eric, C Lai.,. Nai, P.W, Chien, C.C., and Charng, C. Y.. (2003). Composition and antioxidant activity of the essential oil from Curcuma zeodaria. Food Chemistry, 82(4), 583-591.

Muharni, Fitrya, Milanti, O.,and Elfita. (2014). Antibacterial and antioxidant activity of pyranon derivated compound from endophytic fungi Penicillium $s p$ of kunyit putih (Curcuma zeodaria), Traditional Medicine journal, 19(3), 107-112.

Muharni, Fitrya, M.O. Ruliza, D.A. Susanti, and Elfita. (2014b). Di-2Ethylhexyl phtalate and pyranon derivated from endophytic fungi Penicillium sp kunyit putih (Curcuma zeodaria) Indonesian Journal Chemistry, 14(3), 290-296.

Muharni, Heni, Y., Fitrya, and Roni. (2015). Evaluation acute toxicity and antibacterial activity of Penicillium $s p$ endophitic fungus extract of kunyit putih (Curcuma zedoaria) in mice (Mus musculus

L.). Journal Chemical and Pharmaceutical Research, 7(9s), 147-151

Radji, M. (2005). Peranan bioteknologi dan mikroba endofit dalam pengembangan obat herbal. Majalah Ilmu Kefarmasian, 2(3), 113 - 126.

Rodriguez R.J., White, J. T., Arnol, A. E., and Reman, R.S. (2009). Fungal endophytic diversity and funcional roles. New Phytologist, 182(2), 314-330.

Strobel, G and Daisy , B., Castillo, U., and Harper J. (2004). Natural products from endophytic microorganisms. Journal of Natural products, 67(2), $257-268$

Sun, D., Ran, X., and Wang, J. (2008). .Isolation and identification of taxol-producing endophytic fungus from Podocarpus. Acta Microbiologica Sinica. 48, 589595.

Sulistiyani, T. R., Lisdiyanti, P., and Lestari, Y. (2014). Population and diversity of endophytic bacteria associated with medicinal plant Curcuma zedoaria. Microbiology Indonesia, 8(2), 65 - 72

Verma V. C.,Kharmar, R. N., Strobel G. A. (2009). Chemical and functional diversity of natural products from plant associated endophytic fungi. Natural Product Communications, 4(11), 1211-1532

Xu L., Zhou L., Zhao J., Li J., Li X., and Wang J. (2008). Fungal endophytes from Dioscorea zingiberensis and their antibacterial activity. Letters in Applied Microbiology. 46(1), 68-72.

Yannai, S. (2004). Dictionary of food compounds with CD-ROM: Additives, flavors, and ingredients. Boca Raton: Chapman \& Hall/CRC.

Zhang, H. W., Song, Y. C., and Tan, R. X. (2006). Biology and chemistry of endophytes. Natural Product Reports, 23(5), 753-771.

Zhou, K., Ping, W., Li, Q., Hao, S., Zhao, L., and Zhou, D. (2009). Aspergillus niger var taxi, a new species variant of taxol-producing pungus isolated from Taxus cuspidata in China. Journal of Applied Microbiology, 107, 1202-1207. 